\title{
The Rio Health Gym Program: Daily life, leisure and health of older adults
}

Marielle Cristina Gonçalves Ferreiral $\mathbb{D}$ Luiz Fernando Rangel Tura ${ }^{2}$ (D) Rafael Celestino da Silva' 10 Márcia de Assunção Ferreiral $\mathbb{D}$

\section{Abstract}

Objective: to identify the activities performed by older adults as part of the Rio Health Gym Program in their daily lives, and analyze the contributions of these practices to their health and quality of life. Method: a qualitative, exploratory and descriptive study was conducted using interviews with 30 older adults who attended a health center in the city of Rio de Janeiro (RJ). Lexicographic analysis was performed using the Alceste software program. Results: five lexical classes were generated. Physical and leisure activities comprised classes 2 and 3 . The statements that made up the lexical classes showed that older adults carried out their daily activities with autonomy and independence. According to their assessment, the activities promote the integration of participants, increase social participation and benefit health and quality of life. They attribute their proactivity to participation in the social group. Conclusion: the activities bring diversity to daily living, increase socialization and leisure opportunities, and consequently improve the health of older people by facilitating social relationships.

\footnotetext{
Universidade Federal do Rio de Janeiro, Escola de Enfermagem Anna Nery, Programa de Pós-Graduação em Enfermagem. Rio de Janeiro, RJ, Brasil.

2 Universidade Federal do Rio de Janeiro, Instituto de Estudos em Saúde Coletiva, Laboratório de História, Saúde e Sociedade. Rio de Janeiro, RJ, Brasil.

Funding: Conselho Nacional de Desenvolvimento Científico e Tecnológico (CNPq) e Ministério da Ciência e Tecnologia (MCT). Processo no. 310399/2015-7, Bolsa de Produtividade em Pesquisa. Capes Demanda Social, Bolsa de Estudos.

The authors declare there are no conflicts of interest in relation to the present study.

Keywords: Health of the Elderly. Quality of Life. Leisure Activities. Motor Activity. Public Policy. 


\section{INTRODUCTION}

The Active Aging Policy (AAP) promotes opportunities for health, participation and safety, with the aim of improving the quality of life (QOL) of people in the process of aging. The AAP stimulates the perception of physical, social and mental wellbeing during the course of life, participation in society according to people's needs, desires and capacities, and provides protection, safety and adequate care, when necessary. Advanced age does not imply dependency, and therefore, the concept of active aging must be integrated into public health policies ${ }^{1}$.

Economic, political and social crises affect social policies and public institutions with consequences for several sectors, especially social security and health. However, in order for the AAP to achieve the objective of promoting healthy aging, health services need to provide qualified care to the population, through prevention and health promotion. Thus, it is essential that over the course of life, the individual accumulates social, intellectual, financial and health capital, with this being the responsibility of both the individual and the state ${ }^{2}$.

Lifelong, wide-ranging strategies can provide a solid basis for countries to respond to the challenges of population aging. The actions of the state have an important role in population health, ensuring that people have opportunities to live in dignity and access to goods and services that allow them to make healthy choices. In this sense, in addition to the social determinants of health, public policies must consider social determinations, which affect the QoL of the population.

Research carried out in a city in the northeast of the USA with people aged 19-63 years showed that those who took part in leisure activities were more good-humored and had more interests, less stress and lower heart rates than those who did not practice leisure activities, demonstrating the effectiveness of leisure in improving health and well-being ${ }^{4}$.

A study carried out in Japan identified an inverse response between the amount of physical activity performed in one's leisure time and the risk of disability with dementia in men, concluding that a higher level of physical activity should be recommended for younger older adults to prevent disability with dementia ${ }^{5}$. Another study showed an association between higher levels of leisure-time physical activity and a more positive assessment of memory in middle-aged and older adults ${ }^{6}$. In view of this, physical and leisure activities have been recommended for promoting the health of older adults.

In 2011, the Academia da Saúde or Health Gym Program (HGP) was created, one of the strategies articulated with the National Health Promotion Policy (or PNPS), with one of its axes addressing bodily practices and physical activities. This program effectively operates in conjunction with primary health care, which is why its importance in the field of the health of older adults should be highighted, in line with the objective of promoting active aging.

The HGP operates in public spaces created for leisure and physical activities, among other actions such as health education, the production of care and healthy ways of living. Encouraging people's participation in these programs is paramount, as they are committed to health promotion and encourage the acquisition of new habits of healthy living?

Linked to the HGP, in the city of Rio de Janeiro, there is the Academia Carioca da Saúde (the Rio Health Gym) Program (RHGP), linked to the Municipal Health Centers and Family Clinics, offering activities to users of the Brazilian National Health Service (or SUS). The RHGP has a strategic role in the comprehensiveness of health practices and in the expansion of opportunities for users to participate in community-based activities, which serve as an incentive to practice physical activities. There is an increasing number of older participants in the RHGP $^{10}$, which indicates that this is an important field of care, but also of research in the area of health and care for older adults.

The motivational factors for older adults to attend public leisure spaces are related to the search for healthy habits and social interaction ${ }^{11}$. Research carried out with older people in southern Brazil concluded that social support from family and friends are predictors for the participation of older adults in physical activities, and recommends encouraging family members and friends to provide social support 
to older adults to participate in physical activities with a focus on the joint practice of the activity ${ }^{11}$.

Therefore, studies that show the effects of inserting older adults in groups and joint practices of activities as a strategy for healthy aging are highly relevant.

The objectives of this investigation are to identify the activities performed by older members of the Rio Health Gym Program in their daily lives and to analyze the contributions of such practices to health and QoL.

\section{METHOD}

A qualitative, exploratory, descriptive study was carried out from December 2015 to June 2016. Older adults from a Rio Health Gym (RHG) of a Family Health Strategy Clinic (FHSF) in the city of Rio de Janeiro (RJ) participated. The main focus of this program is to promote health and prevent diseases, through the adoption of a healthy lifestyle. It covers the community linked to the FHS, with activities from different sectors of society and the participation of health and physical education professionals. The RHG Program at this FHS Clinic was established in 2011 and provides various activities such as: physical exercises with and without equipment, lectures, craft groups, walking, ballroom dancing, home visits, cultural tours and socializing for member's birthdays.

There were 819 people enrolled in this RHG, 445 of whom participated in one or more activity and of those, 374 were 60 years of age or older. Those aged 60 years or older, who maintained verbal communication skills and cognition, and who had frequented the activities of the RHG for at least 30 days, took part in the study. Older adults with irregular attendance at activities and those who were absent on the days of the study were excluded. Cognitive state was not assessed by the researcher, but was taken from medical records. The sample was selected by convenience, and the sample size was decided upon through the preliminary analysis of the content of 30 interviews, which showed saturation of data ${ }^{12}$ through a panoramic mapping of the contents that allowed the evaluation of the outline of the empirical framework of the research, according to the proposed objectives.
The researcher entered the field to establish links with the participants, publicize the research, invite them to participate verbally and also through the delivery of a letter of invitation, in addition to consulting the records of older adults registered at the gym. For those who accepted, a date was arranged for the application of a questionnaire with closedended questions to characterize the participants (sex, age, marital/conjugal status, education, retirement, residence and length of time of taking part in the activities), and a semi-structured interview script about: daily habits, health care, leisure, establishing relationships between their actions and QoL, activities performed in the RHG, perceptions and assessments. This script was previously tested with three older people from the RHG to verify the clarity of the questions and functionality for achieving the research objectives. The test interviews were discarded and the interviewees were not included in the research sample. After the test, there was no need to change the instrument. The interviews were recorded using an app installed on the cell phone of the researcher, who personally conducted the interviews, at the RHG, with privacy and an average duration of 60 minutes.

The identification data were calculated in percentages and the interviews were transcribed and submitted to the Alceste 2012 software for lexicographic analysis. This software divides the text into elementary context units (ECU) and organizes lexical classes composed of the reduction of the main words used in the discourses to their roots, distributed in frequencies and associations, according to the similarities and/or oppositions of these lexicons, arranged in hierarchical classifications.

After processing the corpus of data formed by the interviews, Alceste divided the text into 1,391 ECUs, made up of 4,447 different words or distinct vocabulary units. The words were reduced to their roots giving rise to 859 analyzable words (nouns, adjectives, verbs) and 266 supplementary forms (articles, pronouns). Five lexical classes were generated. Class 1 deals with the older adults' knowledge of quality of life; Classes 2 and 3 deal with physical and leisure activities provided by the RHG; and Classes 4 and 5 deal with the physiological aspects of health and therapy applied in primary health care. In order to meet the objectives of this article, classes 2 
and 3 and their ascending hierarchical classifications (AHC) were selected, the analysis of which shows the dynamics of class formation by the relations of proximity between lexicons. The ECUs were selected to understand the object in the light of the context and the linguistic traits of the participants.

The study was approved by the Research Ethics Committee in compliance with Resolution No. 466/2012, under opinion number 1.201.027. The participants signed an Informed Consent Form and their identity was preserved by codes: male (M), female $(F)$, a sequential number and age (a).

\section{RESULTS}

A total of 25 women (83.3\%) and five men (16.7\%) participated in the study; the age range ranged from 60 to 82 years, with a predominance of those between
60 to 65 years $(16,53.3 \%)$. In terms of marital status, $16(53.3 \%)$ were married, six $(20 \%)$ were divorced, six $(20 \%)$ were widowed, one $(2 \%)$ was single and one participant did not define herself in any of these categories as she was in a stable relationship but was not married or in a civil union; 27 (90\%) lived with family members and three (10\%) alone; 18 (60\%) were retired.

Lexical Class 2 is composed of 192 ECU, about $20 \%$ of those processed by the program. The words in this class express meanings attributed to leisure activities related to affective relationships (family, friends and co-workers).

According to the AHC (Figure 1), the words: I see, television, watching, visiting and friends, describe actions in the routine of older adults, to enhance friendships. These words are linked to: end, week, see and grandson, which represent an important family relationship.

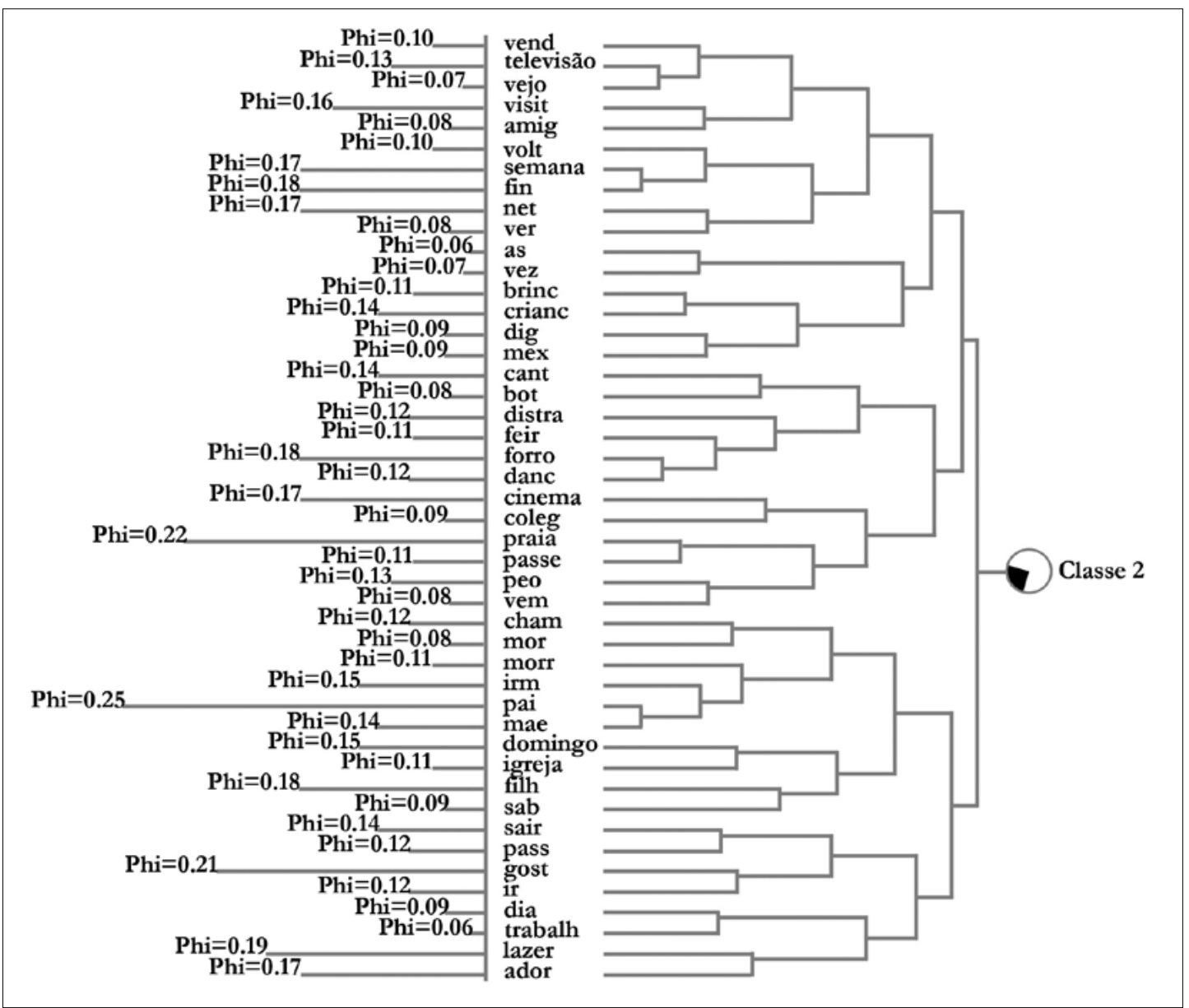

Figure 1. Ascending Hierarchical Classification, Class 2.

Source: Alceste report, 2016. 
The family predominates in the discourses, through the nouns: father, husband, husband, wife, sister, son, daughter, grandson, granddaughter, nephews and nieces, mother. The family arose emerged from the speeches when the older adults were asked about their leisure and routine activities in relation to a satisfactory QoL.

"My daughter lives there in front of the mall. It's hard to get to her house. She says: mom, let's go for a walk in the mall, come over" (F27, 74a).

The lexicons father and mother showed high proximity and frequency, and are linked to the word brother, while both are linked to the term morr (from the verb "morrer", meaning "to die") which represents the death of these people. These terms are linked to living and calling, representing the coexistence of older adults with their parents and siblings.

The ECUs produced by Class 2 suggest that leisure activities for older adults occur in family environments, in contact with and through living with grandchildren and nieces/nephews, in their daily lives and at parties and birthdays of relatives.

\footnotetext{
"My routine is just rushing about. Only on weekends do I have free time, I go to the São Cristóvão market, I travel. Sometimes there are relatives' birthdays, everyone gets together and goes. There's food and drinking, dancing. My whole family loves to dance" (F11, 65a).

"We barbecue and have a lot of fun. All the nieces and nephews. When I go to visit my grandson, I lie on the floor with him, I play" (F26, 63a).
}

Leisure is also characterized by walks, trips to the mall, the cinema, the beach, in the company of family members or by invitation and encouragement from the older adults' children and spouses. Religious practice emerges as a leisure activity, carried out with family members. The AHC shows the connection between the words church and Sunday, both linked to the lexicons son and Saturday, demonstrating the company of children.

\footnotetext{
"Sometimes, when I have nothing to do, I improvise. I call my sister, I agree to meet in the city, just to get out of the house" (F7, 70a).
}

"I like to go to church on Sundays, I go in the morning and at night, my son takes me" (F10, 65a).

The ECUs address friendships in the workplace, socialization and contact with friends. It is observed that the right to a free transport pass makes it possible to expand these leisure and other daily activities:

"Where I worked I left a lot of friends behind and sometimes we meet. Some of them say: come over here. I like that, I go to their house, we drink a beer, chat, laugh, have fun. That's how I like it" (F1, 62a).

"My wife and I go a lot, with our senior travel pass, we take the bus and we go out downtown, we went to the museum, to the beach, we really enjoyed it" (M12, 70a).

Violence and a lack of company emerged in the ECU as the main obstacles to leisure activities:

"I don't have a lot of leisure activities, I don't go out a lot because, due to the violence, sometimes we don't have company to go with us" (F1, 62a).

The AHC highlights the proximity of the words: forró (a type of dance), dancing and the market, which are linked to distraction, representing leisure activities for the enjoyment of older adults. Such words are associated with: cinema, colleague, beach, walking, which are also activities that occupy their time.

In the AHC, the terms I like and go are linked to the lexicons walking and going out, which represent the satisfaction of older adults with their outings. The words: I love, leisure, day and work are connected, highlighting the pleasure, satisfaction and transformation in performing leisure activities and participation in the RHG.

"I don't have much leisure. I try to do more things to distract myself and not spend an empty day. I like to go to relatives' birthdays, I go to the market, I have a beer, I watch people dancing" (F11, 65a).

"I love going out on the street because I distract myself. I like going out. My leisure, I love to listen to forró, I love a beer. My health is fine" (F29, 70a). 
"I like my activities a lot. The days when I don't go, I get bored. I really like it, don't take it away from me [referring to the RHG], otherwise I get bored. I like to walk, when I can, I go. My leisure is sometimes to meet friends "(F30, 60a).

Lexical Class 2 is composed of $192 \mathrm{ECU}$, about $20 \%$ of those processed by the program. The words in this class characterize the routine activities, actions, tasks and responsibilities that older adults perform in their daily lives, as shown in Figure 2.
Class 3 highlights the RHG as part of the daily lives of older adults, whose routine is described by activities performed early in the day, using the lexicon acord (from the verb acordar, or wake up), which represents the beginning of the day.

The words: coffee, I drink, bath/shower, I wake up, I arrive and work represent the beginning of daily activities before and after activities at the gym. This class was composed of ECUs that predominated in the discourses of women, revealing their daily lives to involve domestic chores, represented by the word work.

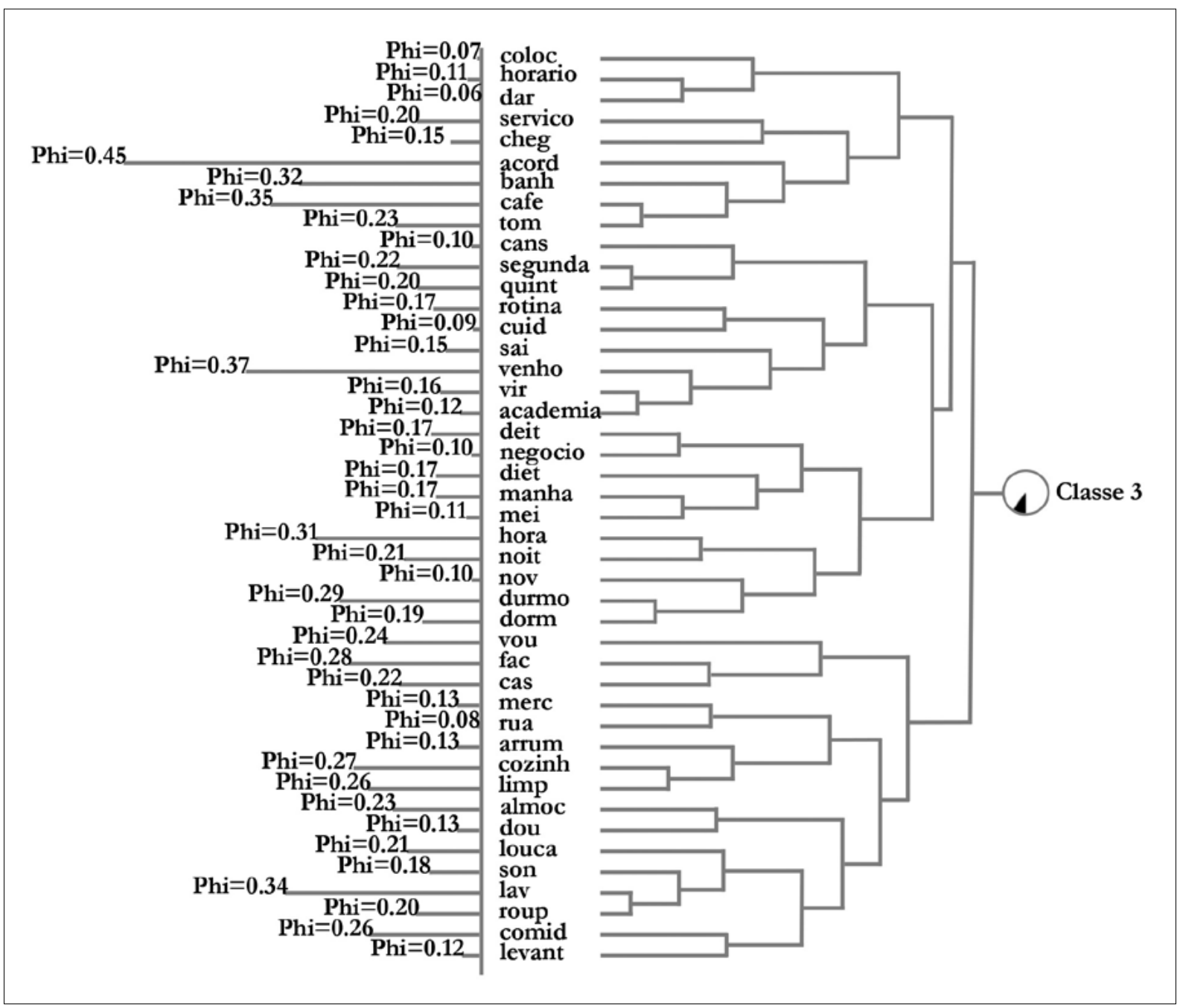

Figure 2. Ascending Hierarchical Classification, Class 3.

Source: Alceste report, 2016. 
In the AHC, it was identified that the words come and gym are connected to I come, I go out, I take care of myself, routine, Monday, Thursday, which together with the word get tired, describe the routine of activities carried out in the RHG, for four consecutive days. There is a predominance of words about the daily practices of caring for oneself, the home and the family:

"I wake up early, have coffee, feed my turtle. I come to the gym, I make lunch, I do handicrafts when there's something for me to do" (F17, 61a).

"I like to come here. I come, get up, drink coffee, come here to the gym, do the activities. I go home, clean, make food. I cook, I get tired" (F13, 79a).

The AHC shows the relationships between the words sleep, wash, clothes, I get up, food, which reflect the need for daytime rest. The words: I sleep, sleep, new, night and time refer to the importance given to sleep and rest. And there is also evidence of the older adults as the caregiver of family members:

"I sleep half an hour after lunch, get up, wash the dishes and do some cleaning somewhere, inside the house. I sit and watch television" (F1, 62a).

"I get up at five in the morning, make coffee, come to the gym, come back home, make lunch, give food to the children and in the afternoon I usually lie down on the couch for a while" (F3, 62 years old).

"My routine is a rotation, it's a rush. I come to the gym, leave and do aqua aerobics. I get home, take care of my mother until about three o'clock" (F30, 60a).

\section{DISCUSSION}

The activities of older adults involve family members, friends and the RHG environment, which can be beneficial for promoting their health and well-being. Such results indicate the transformations that have occurred in the daily life of retired older people, due to the time available for other activities, in addition to the usual tasks of taking care of their home and family, typical of women who make up the majority of participants in this research. For those who were part of the labor market, participation in different activities of their new daily life shows the transition from the social life of the worker to that of the retiree and its impacts on behavior. Participation and engagement in occupational activities allow older adults to have a purpose in life, maintaining their functionality and independence in activities of daily living ${ }^{13}$.

A study that described the perception of the transition from worker to retiree identified that older adults exhibit, at this stage, issues related to the readjustment of life, whether personal or family, social and economic losses, and psycho-emotional and QoL gains. This transition process may be influenced by factors prior to retirement ${ }^{14}$.

The quality of adaptation to retirement can vary according to personal health, emotional, family, social and economic factors. A review study conducted in Brazil concluded that retirement need not be a risk factor for health in all stages of life, nor need it represent a risk factor for depression in older adults ${ }^{15}$. In Sweden, research with a representative sample of the general population, but with a higher level of education, showed in the cross-sectional findings of the first stage of the survey that retired people exhibited better psychological health than those who still worked, and the longitudinal studies of the first and second stages showed that those who retired between the stages of the survey exhibited more positive changes in psychological health than those who still worked or were retired ${ }^{16}$.

Retirement has positive aspects, related to freedom and more time available for relationships and social and leisure activities ${ }^{17}$. The use of time is evident when older adults emphasize the importance of family members in this new routine. The lexicons refer to such members and the activities they demand.

The ECUs indicate that interactions with nieces and nephews, grandchildren and children and the maintenance of bonds with siblings provide older adults with a sense of belonging to the family. Contact with the family allows older adults to socialize and feel valued, in addition to providing relaxation and joy which are good for their health. These family relationships influence well-being. 
People who receive family support develop greater self-esteem that impacts on optimism, affection and mental health ${ }^{18}$. Considering these benefits, good relationships are important, especially when people get older, therefore, strengthening family relationships and interpersonal bonds are confirmed as important for the QoL of older people.

On the other hand, changes in family structure, such as divorce, widowhood, the marriages of children or births of grandchildren, make many older people experience loneliness, as seen in cases where company is absent. Good health and financial independence enable older adults to shoulder their responsibilities and manage their lives. Many are providers for their family nuclei and are satisfied, with a feeling of reciprocity through receiving attention and help from family members in exchange for financial assistance, as compensation for their dedication ${ }^{17}$.

A study carried out in Austria on the importance of intergenerational contact for the health and QoL of older adults states that the proximity and frequency of the coexistence of older adults with grandchildren, children and relatives are important sources for QoL in old age ${ }^{19}$. The leisure activities mentioned by the participants of this study are walking, going to the mall and cinema, and going to church, and they are mostly carried out in the company of family and/ or friends, and contribute to emotional balance and socialization. Research in southern Brazil concluded that greater participation in different leisure activities is associated with a good perception of QoL among the older adults investigated ${ }^{20}$, which reinforces the incentive for this group to increase such activities.

The engagement in socialization and leisure activities involving family and friends is influenced by the actions to promote interaction that are carried out in the RHG group environment, such as trips to theaters, museums, cinemas, parks and beaches. These activities positively affect people, promoting improvements in their physical and psychological well-being. The coexistence in the group creates bonds and when inserted in the daily life, the activities of the RHG transform habits, promoting an active and positive attitude towards life.
The activities carried out in the group environment are part of the daily life of older adults, are motivational and allow them to perceive themselves as useful and feel pleasure in what they do. This positive influence avoids the social isolationism of older adults, which is strongly associated with physical and mental health and presents itself as a major concern for the health of such individuals and also for social policies ${ }^{21,22}$.

Coexistence in groups is important for the contact and establishment of bonds between humans, social belonging, favoring QoL. This impact is seen in the evaluation of the relationship between types and quantity of social activity and QoL, according to sex and age group, with a positive association between an increase in the number of social activities and an increase in $\mathrm{QoL}^{23}$.

The present study revealed a greater number of women involved in the activities of the RHG, explained by the fact that older men tend to practice a greater number of physical activity modalities than women, but older women tend to be more adept at physical activities such as gymnastics and water aerobics in public or outdoor environments ${ }^{24}$, as is the case of the location of this study. This shows the need to rethink the architecture of public environments, leisure areas, museums and squares and to redesign them in order to facilitate the insertion of older adults in such places and allow their use for coexistence, leisure and physical activities. Investing in security and other means of making access for older adults feasible, such as transportation, repaving and other works that prepare these places for the practice of physical activities in order to meet the needs of all.

The predominance of actions that represent the domestic daily life shows that women have an active daily life, divided between the practice of physical activities and the domestic chores that, for the most part, do not constitute limitations for carrying out their activities of daily living, even though they report tiredness after the tasks. Keeping oneself able to perform duties at home can be considered as one of the benefits of undertaking physical activities in RHG. 
The aging process directly interferes with basic activities of daily living, and the practice of physical activities contributes to the autonomy and functional independence of older adults ${ }^{25}$. Independence and autonomy are achievements to be persevered with and, in this sense, the physical activities performed in the RHG, with or without equipment, generically described by older adults in the ECU by terms such as activity and gymnastics, seek to develop the ability to balance and qualities of flexibility, endurance, agility and strength, which are important skills for maintaining activities of daily living ${ }^{26}$.

Busy routines with many tasks and the undertaking of various responsibilities make older adults feel socially valued. Taking care of the family increases their self-perception of usefulness and affects their well-being and the way they deal with old age ${ }^{17}$. On the other hand, it also shows that the task of caring remains strongly linked to the female figure, reaffirming the gender issues involved in the direct care of the home and of people, which can affect women in terms of their social life and physical and mental health. ${ }^{27}$. This may explain, in part, the significant presence in the results of sleep and daytime naps.

The citizenship of the older adults was expressed in the use of the free travel pass to get around the city and for leisure activities. The use of gratuities and discounts on leisure activities indicates awareness of one's rights, an aspect that is also the subject of discussion during activities at RHG.

The Statute for Older Adults guarantees the participation of such individuals in cultural and leisure activities through discounts on tickets and free public transportation for those over 65 years of age, extended, subject to the discretion of local authorities, to older adults from 60 to 65 years $^{28}$.

Mobility and leisure opportunities are impacted by the fear of violence that affects the feeling of security in everyday life and prevents older adults from carrying out leisure activities as they would like. These data can be justified by the fact that the research was carried out in a large urban center, especially in the context of the city of Rio de Janeiro.

Conditions and lifestyle are important factors in the social determination of health and in the promotion of $\operatorname{care}^{29}$. In view of this, the discourses that reflect daily actions denote affect and attitudes and reveal feelings, and the way which one lives generates evaluations, therefore, liking what one does helps to maintain motivation and proactivity, contributing to adherence to the promotion of activities of health.

The recurrent use of the verbs like and adore by older adults characterize the affect mobilized to maintain a life full of activities, including participation in the gym. Hence the importance of professional evaluation and counseling, which help older adults to express their opinions and participate in decisions about care, together with professionals, who can assist them in meeting their needs and desires.

The present study was carried out in a space conducive to the establishment of relationships between health and physical activity, a context that affects the discursive production of its cohabitants. Regarding this incidence, it is observed that the formation of a group social identity can be a powerful determinant of behavior related to physical activity ${ }^{30}$.

Brazil is not yet prepared to deal with its aging population, and needs to adapt its health system and provide public policies aimed at comprehensive care and $\mathrm{QoL}^{31}$. However, it was observed that the Health Gym is part of the National Health Promotion Policy, is aligned with the National Policy for Active Aging, and reflects initiatives to meet the health needs and maintain the functionality of older adults. A review study showed that participation in the activities of the RHG generated positive results in people with chronic diseases and comorbidities ${ }^{10}$, indicating that the program is an ally of health promotion and treatment, in addition to the various initiatives encouraged by gerontology, which excels in the comprehensive approach to health and integrality of the human being. 
In this mission, institutions, clinics, hospitals and health professionals themselves must be more committed to putting into practice values that are incorporated by older adults to promote healthy habits and maintain health conditions. The performance of this study in only one field in a large urban center limits its results. It is recommended that it is expanded to other spaces and groups of older people to deepen the debates and introduce analyzes by gender, age group and varieties of living conditions and daily living. Nevertheless, the contributions reveal the RHG to be a space for promoting health and care, individual and collective, in compliance with the provisions of the active aging policy ${ }^{8}$, therefore, due to the wide range of activities it provides, the program is a fruitful field for interdisciplinary action. In addition, studies have shown that participation in physical activity and leisure programs promoted by the Brazilian government are important factors in the promotion and maintenance of health conditions suitable for QoL in old age ${ }^{32}$.

\section{REFERENCES}

1. World Health Organization. Relatório mundial de envelhecimento e saúde: Resumo [Internet]. Genebra: WHO; 2015 [acesso em 20 fev. 2017]. Disponível em: https://sbgg.org.br//wp-content/uploads/2015/10/ OMS-ENVELHECIMENTO-2015-port.pdf

2. Kalash A. Vested rights, active aging and resiliance: the importance of such concepts throughout life. Rev Bras Geriatr Gerontol [Internet]. 2017 [acesso em 10 mar. 2018];20(2):159-60. Disponível em: http://www. scielo.br/scielo.php?script $=$ sci_arttext\&pid $=\$ 1809$ 98232017000200159\&lng=en

3. Foster L, Walker A. Active and successful aging: a european policy perspective. Gerontologist [Internet]. 2015 [acesso em 10 mar. 2018];55(1):83-90. Disponível em: https://academic.oup.com/gerontologist/ article $/ 55 / 1 / 83 / 570558$

4. Zawadzki MJ, Smyth JM, Costigan HJ. Real-time associations between engaging in leisure and daily health and well-being. Ann Behav Med [Internet]. 2015 [acesso em 15 mar. 2018];49(4):605-15.

Disponível em: https://escholarship.org/content/ qt2qf44682/qt2qf44682.pdf?t=o5hc2t

\section{CONCLUSION}

Daily physical activities, social participation, socializing and interaction with friends in social groups, religious practices, carrying out daily activities with independence and autonomy, support and family contact, the importance of sleep and rest, as well as leisure activities in the company of friends and family, are the main activities performed by and which integrate the daily life of older adults, contributing to their health and QoL.

The RHG represents a public policy that promotes people's health and quality of life through various activities, thereby encouraging active aging, diversifying daily activities, increasing socialization and leisure opportunities for older adults, through which it allows the expansion of social relations, constituting an important public policy for promoting the health of older adults.

Edited by: Ana Carolina Lima Cavaletti
5. Matsunaga T, Naito M, Wakai K, Ukawa S, Zhao W, Okabayashi S, et al. Leisure-time physical activity and risk of disability incidence: a 12 -year prospective cohort study among young elderly of the same age at baseline. J Epidemiol. [Internet]. 2017 [acesso em 17 mar. 2018];27(11):538-45. Disponível em: https:// www.ncbi.nlm.nih.gov/pmc/articles/PMC5608599/

6. Chen YT, Holahan CK, Holahan CJ, Li X. Leisuretime physical activity, subjective age, and self-rated memory in middle-aged and older adults. Int J Aging Hum Dev [Internet]. 2018 [acesso em 17 mar. 2018];87(4):377-91. Disponível em: https://www. researchgate.net/publication/322647715_LeisureTime_Physical_Activity_Subjective_Age_and_SelfRated_Memory_in_Middle-Aged_and_Older_Adults

7. Malta DC, Reis AAC, Jaime PC, de Morais Neto OL, Silva MMA, Akerman M. Brazil's Unified Health System and the National Health Promotion Policy: prospects, results, progress and challenges in times of crisis. Ciênc Saúde Colet [Internet]. 2018 [acesso em 25 maio 2020];23(6):1799-1809. Disponível em: http://www.scielo.br/scielo.php?script=sci_ arttext\&pid $=$ S1413-81232018000601799\&lng $=\mathrm{em}$ 
8. Sá GBAR, Dornelles GC, Cruz KG, Amorim RCA, Andrade SSCA, Oliveira TP, et al. O Programa Academia da Saúde como estratégia de promoção da saúde e modos de vida saudáveis: cenário nacional de implementação. Ciênc Saúde Colet [Internet]. 2016 [acesso em 20 mar. 2018];21(6):1849-60. Disponível em: http://www.scielo.br/scielo.php?script $=$ sci_ arttext\&pid=S1413-81232016000601849\&lng=em

9. Silva EAPC, Silva PPC, Oliveira LS, Santos ARM, Rechia S, Freitas CMSM. Percepção da qualidade do ambiente e vivências em espaços públicos de lazer. Rev Bras Ciênc Esporte [Internet]. 2016 [acesso em 20 mar. 2018];38(3):251-8. Disponível em: http://www. scielo.br/scielo.php?script=sci_arttext\&pid=S010132892016000300251\&lng=em

10. Coração SA, Miranda MG, Dusek PM, Avelar KES. A relevância do programa academia carioca de saúde para a população idosa. Semioses [Internet]. 2019 [acesso em 25 maio 2020];13(1):147-58. Disponível em: http://revistas.unisuam.edu.br/index.php/semioses/ article/view/259

11. Böhm AW, Mielke GI, Cruz MF, Ramirez VV, Wehrmesister FC. Social support and leisuretime physical activity among the elderly: a populationbased study. J Phys Act Health [Internet]. 2016 [acesso em 10 fev. 2019];13(6):599-605. Disponível em: https://journals.humankinetics.com/view/journals/ jpah/13/6/article-p599.xml

12. Saunders B, Sim J, Kingstone T, Baker S, Waterfield J, Bartlam B, et al. Saturation in qualitative research: exploring its conceptualization and operationalization. Qual Quant [Internet]. 2018 [acesso em 10 dez. 2018];52(4):1893-1907. Disponível em: https://link. springer.com/article/10.1007/s11135-017-0574-8

13. Ibrahim SAS, Dahlan A. Engagement in occupational activities and purpose in life amongst older people in the community and institutions. Procedia Soc Behav Sci [Internet]. 2015 [acesso em 20 maio 2019];202:26372. Disponível em https://www.sciencedirect.com/ science/article/pii/S1877042815048788

14. Loureiro HMAM, Mendes AMOC, Camarneiro APF, Silva MAM, Pedreiro ATM. Perceptions about the transition to retirement: a qualitative study. Texto Contexto Enferm [Internet]. 2016 [acesso em 20 maio 2019;25(1):e2260015 [18 p.]. Disponível em: http://www.scielo.br/scielo.php?script $=$ sci_ arttext\&pid=S0104-07072016000100320\&lng=em

15. Silva MM, Turra V, Chariglione IPFS. Idoso, depressão e aposentadoria: uma revisão sistemática da literatura. Rev Psicol IMED [Internet]. 2018 [acesso em 25 maio 2019];10(2):119-36. Disponível em: http://pepsic.bvsalud.org/scielo.php?script=sci_ arttext\&pid=S2175-50272018000200009\&lng=pt\& $\mathrm{nrm}=$ isso
16. Lindwall M, Berg AI, Bjälkebring PAR, Buratti S, Hansson I, Hassing L, et al. Psychological health in the retirement transition: rationale and first findings in the HEalth, Ageing and Retirement Transitions in Sweden (HEARTS) Study. Front Psychol [Internet]. 2017 [acesso em 25 maio 2019];8:1-19. Disponível em: https://www.frontiersin.org/articles/10.3389/ fpsyg.2017.01634/full

17. Areosa SVC. Idosos provedores: a importância dos recursos da aposentadoria para as famílias brasileiras. Barbarói [Internet]. 2015 [acesso em 25 maio 2020];45:173-84. Disponível em https://online.unisc. br/seer/index.php/barbaroi/article/view/5527

18. Thomas PA, Liu H, Umberson D. Family Relationships and Well-Being. Innov Aging [Internet]. 2017 [acesso em 10 de abr. 2019];1(3):1-38. Disponível em https://academic.oup.com/innovateage/ article/1/3/igx025/4617833

19. Kirchengast S, Haslinger B. Intergenerational Ccntacts influence Health Related Quality of Life (HRQL) and subjective well being among austrian elderly. Coll Antropol.[ Internet]. 2015 [acesso em 10 abr. 2019];39(3):551-6. Disponível em: https:// pubmed.ncbi.nlm.nih.gov/26898049/

20. Santos PM, Marinho A, Mazo GZ, Hallal PC. Atividades no lazer e qualidade de vida de idosos de um programa de extensão universitária em Florianópolis (SC). Rev Bras Ativ Fis Saúde [Internet]. 2014 [acesso em 25 maio 2020];19(4):494503. Disponível em: http://docs.bvsalud.org/ biblioref/2016/06/301/artigo-10-santos.pdf

21. Miyawaki CE. Association of social isolation and health across different racial and ethnic groups of older Americans. Ageing Soc [Internet]. 2015 [acesso em 10 abr. 2019];35(10):2201-28. Disponível em: https:// www.cambridge.org/core/journals/ageing-and-society/ article/association-of-social-isolation-and-healthacross-different-racial-and-ethnic-groups-of-older-ame ricans/1CB1D98AAA5EE49D1B587AC4CB6F1F17

22. Cotterell N, Buffel T, Phillipson C. Preventing social isolation in older people. Maturites [Internet]. 2018 [acesso em 15 abr. 2019];13:804. Disponível em: https://www.researchgate. net/publication/324838778_Preventing_Social_ Isolation_in_Older_People

23. Park HK, Chun SY, Choi Y, Lee SY, Kim SJ, Park EC. Effects of social activity on health-related quality of life according to age and gender: an observational study. Health Qual Life Outcomes [Internet]. 2015 [aceso em 11 ago. 2019];13:1-14. Disponível em: https://www.ncbi.nlm.nih.gov/pmc/articles/ PMC4566195/ 
24. Costa TB, Ribeiro LHM, Neri AL. Prevalence of and factors associated with leisure-time physical activity in older adults from seven Brazilian cities: data from the FIBRA study. Rev Bras Ativ Fís Saúde [Internet]. 2015 [acesso em 15 ago. 2019];20(2):174-83. Disponível em: https://rbafs.org.br/RBAFS/article/view/5073/4315

25. Moreira RM, Teixeira RM, Novaes KO. Contribuições da atividade física na promoção da saúde, autonomia e independência de idosos. Rev Kairós [Internet]. 2014 [acesso em 15 ago. 2019];17(1):201-17. Disponível em: https://revistas. pucsp.br/kairos/article/view/20492/15132

26. Sakamoto R, Miura Y. The effect of exercise intervention on frail elderly in need of care: half-day program in a senior day-care service facility specializing in functional training. J Phys Ther Sci [Internet]. 2016 [acesso em 15 ago. 2019];28(7):1957-63. Disponível em: https://www. ncbi.nlm.nih.gov/pmc/articles/PMC4968485/.

27. Ferreira CR, Isaac L, Ximenes VS. Cuidar de idosos: um assunto de mulher? Est Inter Psicol [Internet]. 2018 [acesso em16 ago. 2019];9(1):108-25. Disponível em: http://pepsic.bvsalud.org/scielo.php?script $=$ sci_ arttext\&pid=S2236-64072018000100007\&lng=pt\&t $\operatorname{lng}=\mathrm{pt}$

28. Brasil. Ministério da Saúde. Estatuto do Idoso [Internet]. $3^{\mathrm{a}}$ ed. Brasília, DF: Ministério da Saúde; 2013 [acesso em 25 de maio 2020]. Disponível em: https://bvsms.saude.gov.br/bvs/publicacoes/ estatuto_idoso_3edicao.pdf
29. Derhun FM, Scolari GAS, Castro VC, Salci MA, Baldissera VDA, Carreira L. The coexistence center for elderly people and its importance in the support to the family and the Health Care Network. Esc Anna Nery [Internet]. 2019 [acesso em 02 de set. 2019];23(2):e20180156 [14 p.]. Disponível em: http://www.scielo.br/scielo.php?script $=$ sci arttext\&pid=S1414-81452019000200205\&lng=em

30. Stevens M, Rees T, Coffee P, Steffens NK, Haslam SA, Polman R. A Social Identity Approach to Understanding and Promoting Physical Activity. Sports Med [Internet]. 2017 [acesso em 2 set .2019];47(10):1911-18. Disponível em: https://link. springer.com/article/10.1007/s40279-017-0720-4

31. Miranda GMD, Mendes ACG, Silva ALA. Population aging in Brazil: current and future social challenges and consequences. Rev Bras Geriatr Gerontol [Internet]. 2016 [aceso em 02 set. 2019];19(3):507-19. Disponível em: http://www. scielo.br/scielo.php?script $=$ sci_arttext\&pid=S180998232016000300507\&lng $=\mathrm{em}$

32. Da-fonte E, Feitosa PH, de Oliveira Neto LT, Araújo CL, Figueiroa JN, Alves JG. Effects of a physical activity program on the quality of life among elderly people in Brazil. J Family Med Prim Care [Internet]. 2016 [acesso em 02 set. 2019];5(1):139-42. Disponível em: https://www.ncbi.nlm.nih.gov/pmc/articles/ PMC4943121/ 